\title{
Bedside stratification of patients according to CYP2C19² genotype
}

\author{
Rasa Karaliūtè ${ }^{1}$, \\ Olivija Gustienè $\dot{1}^{1}$ \\ Nora Kupstyte் ${ }^{1}$, \\ Daiva Ambrasiené \\ Vacis Tatarūnas ${ }^{3}$ \\ ${ }^{1}$ Department of Cardiology, \\ Medical Academy, \\ Lithuanian University of Health Sciences, \\ Kaunas, Lithuania \\ ${ }^{2}$ Department of Biology, \\ Faculty of Natural Sciences, \\ Vytautas Magnus University, \\ Kaunas, Lithuania \\ ${ }^{3}$ Institute of Cardiology, \\ Medical Academy, \\ Lithuanian University of Health Sciences, \\ Kaunas, Lithuania
}

Objective. The task was to identify the defective $C Y P 2 C 19^{\star} 2$ allele by using a novel fast-genotyping method in the patients having coronary artery disease who developed stent thrombosis or high on-treatment platelet reactivity.

Materials and methods. A total of 35 patients were included in the study. All the patients were screened for CYP2C19² using Spartan RX CYP2C19 Assay Package.

Results. CYP 2 C $19^{\star} 11^{\star} 1$ variant was found in $63 \%,{ }^{\star} 1^{\star} 2$ in $34 \%,{ }^{\star} 2{ }^{\star}$ in $3 \%$ of patients. The distribution of genotypes was similar in men and women.

Conclusions. By using the bedside technique, CYP2C19*2, which is responsible for a poorer effect of clopidogrel, might be identified in less than an hour.

Keywords: stent thrombosis, CYP2C19, clopidogrel, gender, antiplatelets, genotype

\section{INTRODUCTION}

A considerable amount of progress has been made in stent implantation techniques since the introduction of this method into clinical practice. Nowadays stent thrombosis remains a major life-threatening event following stent implantation. Optimal anti-platelet therapy is one of the most important factors in the prevention of stent thrombosis (Vieira et al., 2013). Current European guidelines recommend dual antiplatelet therapy with a combination of aspirin and a new antiplatelet agent (ticagrelor or prasugrel) as first-line therapy to the patients who

\footnotetext{
* Corresponding author. Email: ambrasiene2007@yahoo.com
}

underwent percutaneous coronary intervention (PCI) and stent implantation (Hamm et al., 2011). Clopidogrel, which was shown to be inferior to ticagrelor or prasugrel, is still used worldwide more often than the new oral antiplatelet agents (Serebruany, Fortmann, 2014).

Clopidogrel, a P2Y12 antagonist, has been used since 2002 for treating acute coronary syndromes (ACS) and in the patients undergoing PCI. Different variability in response to the treatment with clopidogrel is observed worldwide. Usually up to $30 \%$ of patients of European descent are identified as non-responders to clopidogrel antiplatelet therapy (Liu et al., 2011). A lack of a therapeutic clopidogrel effect is associated both with genetic and non-genetic factors. Various studies identified 
CYP2C19 G681A (or ${ }^{\star} 2$ alelle) to be associated with a reduced clopidogrel therapeutic effect. Carriers of at least one ${ }^{\star} 2$ (reduced-function) allele have high on-treatment platelet reactivity and a significantly increased risk of major adverse cardiovascular events (Mega et al., 2010). On 12 March 2010, the Food and Drug Administration (USA) announced a black box warning about Plavix (clopidogrel), which highlighted the impact of ineffective clopidogrel therapy on the carriers of a reduced CYP2C19 enzyme activity (FDA, 2010).

The CYP2C19*17 allele (gain-of-function allele), on the contrary, is responsible for an increased activity of this enzyme. It results in exaggerated bio-activation of clopidogrel and is related to a higher bleeding risk, with average multi-ethnic allele frequencies accounting from 3\% to 21\% (Grosdidier et al., 2011).

Among the non-genetic factors, ethnicity, sex, age, body weight, comorbidities, drug-drug interactions, and other factors might also significantly affect the response to clopidogrel - antiplatelet therapy (Xie et al., 2011).

Newer-generation drugs prasugrel and ticagrelor have a more predictable therapeutic effect and are more potent than clopidogrel (Sabouretand Taiel-Sartral, 2014). Retrospective genetic studies have shown that CYP2C19 did not have any significant effect on the therapeutic effect of newer-generation drugs (Grosdidier et al., 2013). The application of new-generation drugs in clinical practice further remains complicated. Ticagrelor and prasugrel were shown to cause bleeding and other side effects more often than clopidogrel does. It was also shown that clopidogrel was effective enough in the carriers of wild-type $\left({ }^{\star} 1^{\star} 1\right)$ CYP2C19, which represents a normal metabolism rate of this drug (Reese et al., 2012). In addition, only up to one-fourth of the prasugrel-treated patients are discharged from hospital for antiplatelet treatment at home (Sandhu et al., 2013; Bagai et al., 2014).

The available evidence suggests that personalised antiplatelet treatment (drug prescription according to the patients' genotype) is cost-effective. It can provide more clinical value than conventional treatment by reducing the rates of thrombosis or bleeding complications (Li et al., 2014).

As a rule, genotyping in a clinical laboratory is a robust and time-consuming method. Therefore it is hard to apply this method in emergency situations. We used a novel bedside CYP2C19-genotyping equipment which allowed us to determine a patient's CYP2C19 genotype in an hour. By using a novel bedside method, our main task was to determine the defective CYP2C19*2 allele in the sample of the patients with coronary artery disease (CAD) who, following stent implantation, developed stent thrombosis or high on-treatment platelet reactivity, and who required accurate personalized drug therapy. We also wanted to compare the distribution of CYP2C19 2 to a sample of healthy Lithuanian population.

\section{MATERIALS AND METHODS}

\section{Study population}

A total of 35 patients who were admitted to the hospital of the Lithuanian University of Health Sciences Kauno Klinikos at the Department of Cardiology from April 2013 to January 2014 due to CAD (coronary artery disease) and who underwent stent implantation and developed stent thrombosis $45.7 \%(n=16)$ or high on-treatment platelet reactivity $54.3 \%(n=19)$ were included into a further study. Platelet aggregation was measured by using the standard Born method (Born, 1962). Clinical and laboratory data were obtained from case histories. The research was approved by the local Bioethics Committee. All the participants signed informed consent.

\section{Genotyping}

All the patients were screened for the presence of CYP2C19*2 by using Spartan $\mathrm{RX}^{\mathrm{mi}}$ CYP2C19 Assay Package (Package Insert, 01001914_3.28; 08/2013, Spartan Bioscience Inc., Canada). The test was run on the Spartan $\mathrm{RX}^{\mathrm{Ta}}$ platform which automatically extracts and genotypes the patients' DNA. The operation of the pointof-care genetic testing device consisted of the 
following main separate steps intended to be made in less than $8 \mathrm{~min}$ :

1. acquiring a buccal swab;

2. inserting the swab into an assay cartridge;

3. pouring the reaction mix into a genetic testing device and analysing CYP2C19².

The identification of $C Y P 2 C 19 * 2$ carrier was made within $60 \mathrm{~min}$. The results were as follows: homozygous for the wild-type CYP $2 C 19^{\star} 1 /^{\star} 1$, heterozygous ${ }^{\star} 1 /{ }^{\star} 2$ or homozygous ${ }^{\star} 2 /{ }^{\star} 2$.

\section{Statistical analysis}

Results are presented as mean \pm SD; categorical variables are presented in percentage. The Chisquare test was used for categorical variables and the unpaired Student t-test was used for continuous variables. The significance level was set at $p$ value of 0.05 .

\section{RESULTS}

The average age of the studied patients was $63.97 \pm 11.67$ years. About 2/3 (63\%) of the patients studied were males. The patients with STelevation accounted for $37 \%$ of the sample. In total, $86 \%$ of the patients had systemic hypertension, more than a half of the patients studied had dyslipidaemia (57\%), and 25\% were patients with diabetes. Current smokers represented 29\% of the sample. The baseline clinical characteristics of the patients are presented in the Table.

According to the CYP2C19 genotype, a total of 22 patients had wild-type CYP $2 C 19^{\star} 1^{\star} 1$ $(63 \%),{ }^{\star} 1^{\star} 2$ was present in 12 patients $(34 \%)$ and homozygous ${ }^{\star} 2^{\star} 2$ was detected in one patient (3\%).

According to the patients' sex, male patients ( $n=22)$ were younger (61.49 \pm 9.83 years) than female patients $(n=13)(69.30 \pm 13.23$ years $)$, $p=0.05$. CYP2C19* $1{ }^{\star} 2$ was found in $36.4 \%$ $(n=8)$ of male patients. CYP2C19* $11^{\star} 2$ in female patients accounted for $31 \%(n=4)$, one female carried ${ }^{\star} 2^{\star} 2$ variant $(2.9 \%)$.

The distribution of CYP2C19 genotypes in a sample of Lithuanian healthy subjects was already shown in previous studies. The percentage of defective ${ }^{\star} 1^{\star} 2$ and ${ }^{\star} 2^{\star} 2$ variants in a sample of the healthy Lithuanian population
Table. Baseline patient characteristics

\begin{tabular}{|c|c|}
\hline Men (\%) & $22(62.9 \%)$ \\
\hline Age (in years) & $63.97 \pm 11.67$ \\
\hline \multicolumn{2}{|l|}{ Admission diagnosis } \\
\hline STEMI & $13(37.1 \%)$ \\
\hline NSTEMI & $7(20.0 \%)$ \\
\hline UA & $10(28.6 \%)$ \\
\hline SA/positive functional test & $5(14.3 \%)$ \\
\hline \multicolumn{2}{|l|}{ Cardiovascular risk factors } \\
\hline Diabetes mellitus & $9(25.7 \%)$ \\
\hline Systemic hypertesnion & $30(85.7 \%)$ \\
\hline Dyslipidaemia & $20(57.1 \%)$ \\
\hline Current smoker & $10(28.6 \%)$ \\
\hline \multicolumn{2}{|l|}{ Cardiovascular history } \\
\hline Previous MI & $17(48.6 \%)$ \\
\hline Previous CABG & $4(11.4 \%)$ \\
\hline \multicolumn{2}{|l|}{ Angiographic characteristics } \\
\hline One vessel treated & $28(80.0 \%)$ \\
\hline Two vessels treated & $6(17.1 \%)$ \\
\hline Drug-eluting stents & $8(22.9 \%)$ \\
\hline Thrombotic lesion & $16(45.7 \%)$ \\
\hline In-stent restenosis & $10(28.6 \%)$ \\
\hline
\end{tabular}

CABG - coronary artery bypass grafting; MI - myocardial infarction; NSTEMI - non-ST elevation myocardial infarction; PCI - percutaneous coronary intervention; STEMI - ST elevation myocardial infarction; UA - unstable angina; SA - stable angina.

$(n=279)$ was lower $\left(23.3 \%\right.$ of intermediate ${ }^{\star} 1^{\star} 2$ and $0.7 \%$ of poor metabolizer $\left.{ }^{\star} 2^{\star} 2\right)(p=0.1$ for $\left.{ }^{\star} 1{ }^{\star} 2\right)$ as compared with the patient sample (Tatarūnas et al., 2012).

\section{DISCUSSION}

The CYP2C19*2 allele (loss-of-function) is the most common type among the reducedfunction genes and is associated with a reduced antiplatelet effect of clopidogrel and the increased risk for adverse cardiovascular events (Grosdidier et al., 2011). About 15\% of the Caucasians, $29-35 \%$ of the Asians, and $25 \%$ of the African Americans have at least one CYP2C19*2 allele (Rosemary, Adithan, 2007; Shetkar et al., 2014). Other CYP2C19 variants 
$\left({ }^{\star} 3,{ }^{\star} 4,{ }^{\star} 5,{ }^{\star} 6,{ }^{\star} 7\right.$, and ${ }^{\star} 8$ alleles $)$ are also identified as having an impact on clopidogrel metabolism and therapeutic activity. Their frequency in the Caucasian population is relatively low $(<1 \%)$ (Siller-Matula et al., 2013). According to our data, intermediate $\left({ }^{\star} 1^{\star} 2\right)$ and poor metabolizer $\left({ }^{\star} 2^{\star} 2\right)$ CYP2C19 genotypes were observed in $34 \%$ and in $3 \%$ of our patients, respectively. We also compared the distribution of these genotypes in a sample of healthy Lithuanian subjects. The percentage of defective ${ }^{\star} 1^{\star} 2$ and ${ }^{\star} 2 \star 2$ variants in a sample of the Lithuanian population is lower than that in the sample of the patients (Tatarūnas et al., 2012).

The male patients studied were younger than the female patients. The frequency of ${ }^{\star} 1^{\star} 2$ was similar in male and female patients. Sex differences have been described to have an impact on the response to antiplatelet therapy. Hobson and his colleagues demonstrated that there were both an elevated baseline clotting tendency and a reduced response to clopidogrel in young healthy females as compared to that in males. No such differences among males and females were observed in an older or postmenopausal female (Hobson et al., 2009). By contrast, males had a higher risk of developing CAD as compared with females, with the highest relative risk in young adults. The postmenopausal women had the same incidence of CAD as men. This might be accounted by a lack of estrogen, which can also inhibit the platelet function or have a positive effect on endothelium (Meyer et al., 2011; Kytö et al., 2015). There are other scientific data available suggesting that females have a higher metabolic activity of CYP2C19 and a higher level of active clopidogrel metabolite than males (Xie et al., 2014). Nevertheless, clopidogrel reduces the risk of cardiovascular events in both women and men (Berger et al., 2009).

The latest European guidelines emphasized that platelet function testing or genetic testing should not be recommended in routine clinical practice on account of insufficient prospective data (Hamm et al., 2011). More and more data, however, are available about the benefit of phenotyping and genotyping to selecting antiplatelet treatment following PCI (Montalescot et al.,
2013; Kolh et al., 2014). A rapid gene trial showed a successful validation and clinical application of point-of-care genetic testing in selecting effective treatment following PCI (Roberts et al., 2012). Stimpfle and his colleagues also demonstrated that CYP2C19 loss-of-function point-ofcare genotyping identified the $C Y P 2 C 19^{\star} 2$ allele carriers and enabled those patients to be identified who did not respond well to conventional treatment and allowed effective treatment to be prescribed on the basis of the established genotype (Stimpfle et al., 2014). The method, which was used by our research group, allows a bedside identification of the patient's CYP2C19 genotype in an hour. Thus, this might help differentiate the patients who respond to treatment with clopidogrel from those for whom treatment with clopidogrel is ineffective.

Fast and accurate genotyping and personalized antiplatelet can be more cost-effective and may provide fewer adverse outcomes as compared with the empirical drug dosage.

\section{CONCLUSIONS}

By using the bedside technique, CYP2C19*2, which is responsible for a poorer effect of clopidogrel, can be identified in less than an hour. The CYP2C19^ $1^{\star} 2$ was more frequent among patients than in the healthy population sample.

\section{CONFLICT OF INTEREST}

None declared.

Received 9 January 2018 Accepted 7 May 2018

\section{References}

1. Bagai A, Wang Y, Wang TY, Curtis JP, Gurm HS, Shah B, et al. In-hospital switching between clopidogrel and prasugrel among patients with acute myocardial infarction treated with percutaneous coronary intervention: insights into contemporary practice from the National Cardiovascular Data Registry. Circ Cardiovasc Interv. 2014; 7(4): 585-93. 
2. Berger JS, Bhatt DL, Cannon CP, Chen Z, Jiang $\mathrm{L}$, Jones JB, et al. The relative efficacy and safety of clopidogrel in women and men a sexspecific collaborative meta-analysis. J Am Coll Cardiol. 2009; 54(21): 1935-45.

3. Born GV. Aggregation of blood platelets by adenosine diphosphate and its reversal. Nature. 1962; 194: 927-9.

4. FDA Drug Safety Communication: reduced effectiveness of Plavix (clopidogrel) in patients who are poor metabolizers of the drug. Available at: http://www.fda.gov/Drugs/DrugSafety/ Postmarket DrugSafetyInformationforPatientsandProviders/ucm203888.htm. [Cited 2010 April 28]

5. Grosdidier C, Quilici J, Loosveld M, Camoin L, Moro PJ, Saut N, et al. Clinical Pharmacogenetics Implementation Consortium. Clinical Pharmacogenetics Implementation Consortium guidelines for cytochrome P450-2C19 (CYP2C19) genotype and clopidogrel therapy. Clin Pharmacol Ther. 2011; 90(2): 328-32.

6. Grosdidier C, Quilici J, Loosveld M, Camoin L, Moro PJ, Saut N, et al. Effect of CYP2C19*2 and ${ }^{\star} 17$ genetic variants on platelet response to clopidogrel and prasugrel maintenance dose and relation to bleeding complications. Am J Cardiol. 2013; 111(7): 985-90.

7. Hamm CW, Bassand JP, Agewall S, Bax J, Boersma E, Bueno $\mathrm{H}$, et al. ESC Committee for Practice Guidelines. ESC Guidelines for the management of acute coronary syndromes in patients presenting without persistent ST-segment elevation: The Task Force for the management of acute coronary syndromes (ACS) in patients presenting without persistent ST-segment elevation of the European Society of Cardiology (ESC). Eur Heart J. 2011; 32(23): 2999-3054.

8. Hobson AR, Qureshi Z, Banks P, Curzen N. Gender and responses to aspirin and clopidogrel: insights using short thrombelastography. Cardiovasc Ther. 2009; 27(4): 246-52.

9. Kolh P, Windecker S, Alfonso F, Collet JP, Cremer J, Falk V, et al. Task Force on Myocardial Revascularization of the European Society of
Cardiology and the European Association for Cardio-Thoracic Surgery; European Association of Percutaneous Cardiovascular Interventions. 2014 ESC/EACTS Guidelines on myocardial revascularization: the Task Force on Myocardial revascularization of the European Society of Cardiology (ESC) and the European Association for Cardio-Thoracic Surgery (EACTS). Developed with the special contribution of the European Association of ercutaneous Cardiovascular Interventions (EAPCI). Eur J Cardiothorac Surg. 2014; 46(4): 517-92.

10. Kytö V, Sipilä J, Rautava P. Association of age and gender with risk for non-ST-elevation myocardial infarction. Eur J Prev Cardiol. 2015; 22(8): 1003-8.

11. Li J, Jian Z, Song M, Guo W, Chen G, Lu W, et al. Tailored antiplatelet therapy and clinical adverse outcomes. Heart. 2014; 100(1): 41-6.

12. Liu Y, Liu N, Li W, Shao H. Clopidogrel response variability and its correlation with early recurrent cardiovascular events in chinese patients undergoing percutaneous coronary intervention. Pharmacology. 2011; 87(5-6): 321-30.

13. Mega JL, Simon T, Collet JP, Anderson JL, Antman EM, Bliden K, et al. Reduced-function CYP2C19 genotype and risk of adverse clinical outcomes among patients treated with clopidogrel predominantly for PCI: a metaanalysis. JAMA. 2010; 304(16): 1821-30.

14. Meyer DM, Eastwood JA, Compton MP, Gylys K, Zivin JA, Ovbiagele B. Sex differences in antiplatelet response in ischemic stroke. Womens Health Lond Engl. 2011; 7(4): 465-74.

15. Montalescot G, Sechtem U, Achenbach S, Andreotti F, Arden C, Budaj A, et al. (Task Force Members). 2013 ESC guidelines on the management of stable coronary artery disease: the Task Force on the management of stable coronary artery disease of the European Society of Cardiology. Eur Heart J. 2013; 34(38): 2949-3003.

16. Reese ES, Daniel Mullins C, Beitelshees AL, Onukwugha E. Cost-effectiveness of cytochrome P450 2C19 genotype screening for 
selection of antiplatelet therapy with clopidogrel or prasugrel. Pharmacotherapy. 2012; 32(6): 323-32.

17. Roberts JD, Wells GA, Le May MR, Labinaz M, Glover C, Froeschl M, et al. Point-of-care genetic testing for personalisation of antiplatelet treatment (RAPID GENE): a prospective, randomised, proof-of-concept trial. Lancet. 2012; 379(9827): 1705-11.

18. Rosemary J, Adithan C. The pharmacogenetics of CYP2C9 and CYP2C19: ethnic variation and clinical significance. Curr Clin Pharmacol. 2007; 2(1): 93-109.

19. Sabouret P, Taiel-Sartral M. New antiplatelet agents in the treatment of acute coronary syndromes. Arch Cardiovasc Dis. 2014; 107(3): 178-87.

20. Sandhu A, Seth M, Dixon S, Share D, Wohns D, Lalonde T, et al. Contemporary use of prasugrel in clinical practice: insights from the Blue Cross Blue Shield of Michigan Cardiovascular Consortium. Circ Cardiovasc Qual Outcomes. 2013; 6(3): 293-8.

21. Serebruany VL, Fortmann SD. Viewpoint: "underutilisation of novel antiplatelet agentsmyths, generics, and economics". Thromb Haemost. 2014; 112(1): 4-9.

22. Shetkar SS, Ramakrishnan S, Seth S, Chandna P, Verma SK, Bhargava B, et al. CYP 450 2C19 polymorphisms in Indian patients with coronary artery disease. Indian Heart J. 2014; 66(1): 16-24.

23. Siller-Matula JM, Trenk D, Schrör K, Gawaz M, Kristensen SD, Storey RF, et al. EPA (European Platelet Academy). Response variability to P2Y12 receptor inhibitors: expectations and reality. JACC Cardiovasc Interv. 2013; 6(11): 1111-28.

24. Stimpfle F, Karathanos A, Droppa M, Metzger J, Rath D, Müller K, et al. Impact of point-of-care testing for CYP2C19 on platelet inhibition in patients with acute coronary syndrome and early dual antiplatelet therapy in the emergency setting. Thromb Res. 2014; 134(1): 105-10.
25. Tatarūnas V, Jankauskienė L, Kupstytė N, Gegieckienè R, Gustienè O, Lesauskaitė V. Personalized treatment with clopidogrel: the research on the impact of the CYP 2C19 (G681A) polymorphism and of clinical factors on the antiplatelet treatment with clopidogrel. Lietuvos bendrosios praktikos gydytojas. 2012; 16(3): 146-151.

26. Vieira MS, Luz A, Anjo D, Antunes N, Santos M, Carvalho H, et al. Triple, simultaneous, very late coronary stent thrombosis. Rev Port Cardiol. 2013; 32(3): 247-52.

27. Xie HG, Zou JJ, Hu ZY, Zhang JJ, Ye F, Chen SL. Individual variability in the disposition of and response to clopidogrel: pharmacogenomics and beyond. Pharmacol Ther. 2011; 129(3): 267-89.

\section{Rasa Karaliūtė, Olivija Gustienė, Nora Kupstytė, Daiva Ambrasiené, Vacis Tatarūnas}

\section{IŠEMINE ŠIRDIES LIGA SERGANČIŲ PACIENTŲ IDENTIFIKAVIMAS PAGAL CYP2C19^2 GENOTIPA}

\section{Santrauka}

Išemine širdies liga sergantiems pacientams, kuriems išsivysto stento trombozė arba gydant antiagregantais nustatomas didelis trombocitų reaktyvumas, siekème nustatyti patologini $\mathrm{CYP} 2 \mathrm{C} 19^{\star} 2$ alelį, taikydami naują greitai genotipą nustatantị metodą. Iš viso tyrime dalyvavo 35 pacientai. Visi pacientai buvo ištirti dèl CYP2C19^2 naudojant Spartan RX CYP2C19 tyrimų paketą. CYP2C19* $1^{\star} 1$ genetinis variantas nustatytas $63 \%,{ }^{\star} 1^{\star} 2-34 \%$, ${ }^{\star} 2^{\star} 2-2 \%$ tirtų pacientų. Vyrų ir moterų grupèse skirtingi genotipai pasiskirste panašiai. CYP2C19*2 alelį, lemiantị blogesnị klopidogrelio antitrombocitini efektą, greitu genotipo identifikacijos metodu galima nustatyti greičiau nei per valandą.

Raktažodžiai: stento tromboze, CYP2C19 variantas, klopidogrelis, lytis, antiagregantai 